\title{
THE POPULIST ELITE PARADOX: USING ELITE THEORY TO \\ ELUCIDATE THE SHAPES AND STAKES OF POPULIST ELITE CRITIQUES
}

\author{
Marte Mangset, Fredrik Engelstad, Mari Teigen \\ and Trygve Gulbrandsen
}

\begin{abstract}
Critiques of elites define populism, which conceives of power relations as a unified, conspiring elite exploiting the good people. Yet, populism itself is inherently elitist, calling for a strong leader to take power and channel the will of the people. Elite theory, surprisingly overlooked in scholarship on populism, can clarify this apparent paradox and elucidate the dimensions of populism and its risk of authoritarianism in new ways. In contrast to populist ideological conceptions of power relations in society, elite theory points to the possibility that several elites with diverging voices and interests exist. Furthermore, elite theorists argue that such elite pluralism is a necessary component of a well-functioning democracy. Much scholarship on populism, often aiming to understand its causes and focussing on Western Europe and North America, points to the similarities of populist movements. The focus on similarities strengthens the understanding of populism as a uniform phenomenon and populist elite critiques as homogeneous. However, broader comparative studies show that different populist movements target a range of various elite groups. Indeed, the empirical reality of populist elite critiques targeting diverse elite groups is more in line with elite theory than populist ideological
\end{abstract}

Elites and People: Challenges to Democracy

Comparative Social Research, Volume 34, 203-222

Copyright (C) 2019 by Marte Mangset, Fredrik Engelstad, Mari Teigen and Trygve Gulbrandsen

Published by Emerald Publishing Limited. This chapter is published under the Creative Commons

Attribution (CC BY 4.0) licence. Anyone may reproduce, distribute, translate and create derivative works of this chapter (for both commercial and non-commercial purposes), subject to full attribution to the original publication and authors. The full terms of this licence may be seen at http://creativecommons.org/licences/by/4.0/legalcode ISSN: 0195-6310/doi:10.1108/S0195-631020190000034010 
conceptions of power relations in society. A key to grasping the democratic challenges posed by the power relations between elites and masses in both populist critiques and populist solutions is an understanding of the institutional conditions for elite integration versus elite pluralism. This central discussion in both classical and modern elite theory is applied to analyse populism in this contribution.

Keywords: anti-elitism; authoritarianism; democracy; elite pluralism; elite theory; populism

\section{THE POPULIST ELITE PARADOX}

The current rise of populism across the world has revived classical questions about power relations between the elites and masses and the related democratic challenges. Populism, on one hand, is a salient response to the unequal distribution of power and privilege, but on the other hand, populism has its own problematic understandings of the relationship between the people and elites. How does populist ideology conceptualise these power relations, and in what way are these conceptualisations democratically challenging?

Critiques of elites define populism, which conceives of power relations as a group of conspiring elite exploiting the good people. However, populism is also inherently elitist, calling for a strong leader to take power and channel the will of the people. The understanding of the wicked elite as a homogeneous, united group with common interests is bearer of elitism in a very specific manner. So does the populist understanding of a more adequate leadership as a leader who, freed from intermediate elites and institutional obstacles, voices and promotes the people's interests. Elite theory, surprisingly overlooked in scholarship on populism, can clarify the apparent paradox of populist elitism and elucidate the dimensions of populism and its risks of authoritarianism in new ways.

In contrast to the ideal-typical populist conception of power relations in society, elite theory points to the possible plurality of elites: elites at different hierarchical levels of power and elites in different sectors of society - with possibly diverging interests. Furthermore, in contrast to the populist concept of a political leader with an adequate relationship with the people, elite theory argues that a certain degree of separation between different elite groups is necessary for a well-functioning democracy (Aron, 1950). This chapter explores the opposition between populist ideological understandings of elites and elite theory's conceptualisations of elites and their relations with the people in order to shed new light on populism.

However, to grasp populist perceptions of the relationship between the elites and masses, we must look beyond its ideal-typical ideological conceptualisations and explore the more composite empirical reality. Much empirical scholarship on populist movements, often aiming at understanding its causes and focussing on Western Europe and North America, points to their similarities. In particular, several scholars stress the strength of the cultural thesis (in which anti-immigrant voters criticise the liberal political elites) over the economic and institutional theses in explaining the rise of populism. These studies reinforce the understanding 
of populism as uniform, voicing a homogeneous elite critique. However, broader comparative studies show that different populist movements target a range of elite groups. West European and North American populists attack cultural and political elites for being too liberal, Eastern and Southern European populists criticise their political elites for being corrupt, and South American populists direct anger towards economic elites. Moreover, populist movements often attack different intermediate elites, such as the leaders of political parties, central banks, employer organisations and unions. Broad, comparative approaches uncover the empirical reality of populist elite critiques targeting diverse elite groups. These critiques are more in line with elite theory's conceptualisations of elite pluralism than populist ideologies' conceptualisations of power relations in society.

The key to understanding the democratic challenges of the power relations between the elites and masses in populist critiques and populist solutions is the question of degrees of elite pluralism and elite integration, a question much debated in elite theory. The populist ideological perception of the elite as uniform and conspiring should be taken seriously in the sense that it should be object of empirical scrutiny. Elite theory contributes analytical tools to scholarship on populism that can be fruitfully used to investigate descriptively whether elites are integrated and homogeneous and to discuss normatively how such unity may represent a challenge to democracy. In this chapter, elite theory and new combinations of existing research on populism are used to discuss theoretically the relationship between the degrees of elite pluralism, institutional conditions for such pluralism and elitist character of populism.

Our discussion on populist ideologies' conceptualisations of power relations and politics draws on empirical and theoretical scholarship on populism, and we construct an ideal-typical model of populist ideologies based on this scholarship. The model might not be accurate for all versions of populist ideologies, but it incorporates key features found in the various definitions and versions of populism and serves as an analytical tool for discussing other conceptualisations of elite-mass relationships. We consider these ideological conceptualisations to be narratives on which populist leaders often draw when mobilising voters and followers.

We further compare these populist ideological conceptualisations to elite theoretical conceptualisations of elite-mass relationships initially developed by elite theorists with more descriptive, analytical goals. However, the analytical tools in elite theory are thought to also provide a more informed point of departure for making a normative assessment of elite-mass relationships. Although these two types of conceptualisations have somewhat different statuses, they can be fruitfully discussed in relation to each other. They are both intended to describe the power relations between the elites and masses in ways that enable normative assessment of those relations. We lay out these two types of conceptualisations.

\section{ANTI-ELITISM AS THE DEFINING FEATURE OF POPULISM}

Among the numerous approaches and definitions of populism, a basic set of criteria has gained agreement from most scholars: Margaret Canovan's (1981, 
p. 294, 1999) minimalist definition that all populist ideologies express anti-elitism and in some way exalt the people, whatever that term may refer to. An elite critique is always part of the definition whether one sees populism as a class-based movement related to large-scale societal transformation, a response to economic grievances and political institutional failures such as corruption or a specific set of ideas about society and how politics work (Silva, 2017, pp. 11-17). Those who focus on the political dimension of populism, perceiving it as a discourse (Laclau, 2005), political style (Knight, 1998), thin-centred ideology (Mudde, 2004) or a form of mobilisation (Meny \& Surel, 2001), all incorporate a fundamental opposition between the good people (the majority) and the wicked elite (the minority; Silva, 2017, p. 12). Populism is anti-elite.

Central to the definition of populism is the homogeneity of the people who are good and have a common general will and set of values, interests and desires (Mudde, 2004; Taggart, 2000). It, therefore, follows that there is no room for disagreement or fundamental differences within the people (Silva, 2017, pp. 14-15). Populism, thus, clearly opposes pluralism and the idea of democracy as a space where diverging interests can be debated and decided. Populist ideologies conceiving of the people as homogeneous and good in this specific manner also need the other half of this complementary Manichean whole: the wicked elite minority who exploits the people. The people are the underdog in the power relations, and the goal of the populist movement is to reverse those relations. Populist ideologies present the exploitation by the elite as motivated by the wish to protect the special interests of this minority group considered to be illegitimate and opposed to the people's general will. The elite is perceived as a homogeneous entity, united in the interest of exploiting the people.

\section{POPULISM AS ELITISM}

To develop into a broad movement, populism depends on the formation of its own leadership - its own elite. The question is how this elite should be shaped and how the power relations between the leader and the movement are conceptualised. Although it might seem paradoxical, populist conceptions of this relationship can be described as particularly elitist in a multifaceted way. First, populist movements generally favour strong leaders. When thinking of empirical examples of strands of populism, we generally associate populist movements with strong, charismatic leaders, such as Geert Wilders in the Netherlands, Vladimir Putin in Russia and Jean-Luc Mélenchon in France. Mudde (2004) argues that a charismatic leader does not define populist movements, but that the choice of such a leader generally follows from the defining element of a leader who interprets and expresses the people's general will without debating or confronting their interests and ideas.

Second, an element defining populism and underpinning its elitism is the idea of a direct connection between the people and a leader. Leaders of populist movements should not educate or try to change the people but rather should express their desires and will. Populist leaders should forge policy that directly expresses that will (Canovan, 1999; Kazin, 1998; Mudde, 2004; Silva, 2017). The idea of the 
people as a homogeneous entity with a common general will is central to populism's conceptualisation of its own leadership. The single person who takes on the leadership role in a populist movement should be able to interpret and appropriately articulate the people's desires and will. The leader should not demonstrate independent or creative leadership but simply embody and transmit the people's general will.

Although this leadership style can be interpreted as anti-elitist and very democratic and is often presented as such by populist leaders, this direct relationship between the electorate and its leader does open to a particular form of elitism. Populist ideologies argue that to be able to channel the people's will, the leader should be free from institutional constrains and interfering intermediate elites thought to be prone to promote their own interests rather than the people's interests. This conceptualisation of adequate policy leadership as based on a direct connection between the people and the leader unmediated by interfering or obstructing elites is itself elitist. It allows for a concentration of power in the hands of the leader and a very narrow elite, freed from possible counter-elites. A feature of populist ideologies and their conceptualisations of legitimate power relations between the leader and the people thus are the dismissal of intermediate elites and a plurality of elites as illegitimate.

A third element underpinning elitism in populist ideological conceptualisations of the relationship between the governing and the governed is the way in which political leaders are legitimised. Charismatic authority rather than rational-legal authority (Weber, 1992 [1921]) is held up as the source of legitimacy for populist leaders. Although populist parties indeed gain legitimacy through democratic elections, this legitimacy is based on a very thin understanding of democracy. The populist idea of the leader as one who directly interprets and channels the will of the people represents a conception of politics markedly different than liberal democracy (Dahl, 1989). Furthermore, this populist understanding of the relationship between the leader and the governed distinguishes itself from the idea of politics as a process in which various groups deliberate and compete for approval of their views and interests - also in the political decision-making and implementation processes after elections. Populist leaders are not expected to deliberate rationally with other power bases in the government apparatus or to limit their own power by rules and procedures because they are thought to be those who truly know what the people want. Charismatic leadership is a central tool for populist leaders to gain legitimacy as the true interpreters of the people's will. They often have an aura of being a godsend akin to kings' divine nature: therefore, their judgment and actions are the most adequate means to detect what the people's general will is (Silva, 2017, p. 15). Such an interpretation of charismatic leadership is quite in line with Weber's (1992 [1921]) understanding of charismatic authority. Giving power to a leader on the top to judge the correct interpretations of the people's will and the appropriate policy to achieve it has a deeply elitist nature. Table 1 summarises these three elements characteristic of the populist ideas of adequate political leadership.

Populist ideology ideal typically thus both describes the political situation as characterised by a united, oppressive elite and suggests making changes in power 
Table 1. Elements Contributing to the Elitist Character of Populist Ideal-Typical Leadership.

\begin{tabular}{lll}
\hline $\begin{array}{l}\text { Components of Populist Ideal-Typical } \\
\text { Leadership }\end{array}$ & $\begin{array}{l}\text { Pathway to Elitism (Concentration of Power } \\
\text { in a Narrow Elite) }\end{array}$ \\
\hline 1 & Image of a strong leader & $\begin{array}{l}\text { Legitimises leaders who make decisions and } \\
\text { take action based on their own judgment } \\
\text { Delegitimises counter-voices, deconcentration } \\
\text { of power at the top and institutional } \\
\text { constraints on leadership }\end{array}$ \\
3 & $\begin{array}{l}\text { Direct relationship between the people } \\
\text { and the leader }\end{array}$ & $\begin{array}{l}\text { interpreter of the people's will hinders } \\
\text { exchange of ideas and opinions and } \\
\text { protects the leader from critique }\end{array}$ \\
\hline
\end{tabular}

relations that also concentrate power in the hands of a narrow, united elite. This is the paradox of populist elitism. This solution, however, is clearly presented as not elitist but as a way of handing power to the people. Analytical tools from elite theory, thus, make clear the elitist character of populism. Before addressing in more depth why the populist solution of political leadership is democratically problematic and whether the populist diagnosis of a united, homogeneous elite is accurate, we look at how elite theory analyses the relationship between the elites and masses.

\section{CLASSICAL CONCEPTUALISATIONS OF ELITE PLURALISM}

Classical elite theory, surprisingly overlooked in scholarship on populism, provides analytical tools for discussing the relationship between elite pluralism and power and clarifying the paradox of populist elitism. The opposition between the ruling minority elite and the ruled masses conceived in populism is a core point in Vilfredo Pareto's (1963) and Gaetano Mosca's (1939 [1896]) contributions to classical elite theory. Normatively, the fundamental views of Pareto and Mosca are quite different from populist ideologies and see ruling elites as a necessary, valuable organisation of politics and society. The authors consider all societies to be necessarily hierarchised and believe egalitarian distribution of power to be impossible. Populist ideologies, in contrast, are based on the idea that it is possible and preferable to take power from elites and give it to the people (Coenen-Huther, 2004). Nevertheless, Pareto's and Mosca's understandings of the relationship between the elite minority and the ruled majority analytically resonate with populist ideological understandings of the relationship between the people and elites as both sides consider the people to be dominated by elites. However, elite theory, developed for a quite different purpose than populist ideologies, offers a more nuanced understanding of these power relations.

In addition to the binary opposition between the rulers and the ruled majority, Pareto (1963, p. 1423) is most famous for defining elites as those who possess the knowledge and skills that make them the best in their areas of activity, whether 
they are the best chess players, the best political leaders or the best thieves. This is a concept of elite delimited to specific occupational fields and can be characterised as expert or professional elites (Mangset, 2015). In many respects, Pareto's (1963) understanding is compatible with a meritocratic understanding of elites as groups that deserve privileges and power in specific fields, a conception clearly opposed to the populist assessment of the legitimacy of elite domination. Pareto wrote that the most able rulers have power over elites in other fields, as well as over the masses. Nevertheless, his specification of capable elites in a range of different fields implies a certain degree of pluralism. A concept connecting elites to excellence within a specific field necessarily implies a plurality of elites. ${ }^{1}$ Although Pareto does not necessarily consider this to imply dispersion of power, he provides an analytical tool for thinking of the possibility of such dispersion of power and connecting it to elite pluralism.

Mosca's (1939 [1896]) writings highlight another tension between elites. In addition to the binary opposition among the ruled majority and the ruling minority, Mosca draws a distinction between different levels of elites: the political elites, who are the ones truly governing, and a broader set of intermediate elites between the top group and the general population. These mediators are necessary for governing; without them minority rule, even 'any sort of social organization would be impossible' (Mosca, 1939 [1896], p. 404). Here, too, emerges the germ of a pluralist conception of elites. Moreover, Mosca envisages a counter-elite, 'another ruling class or directing minority necessarily forms ... antagonistic to the class that holds possession of the legal government'. A plurality of elites functions as an opposition that may 'seriously embarrass an official government' (Mosca, 1939 [1896], p. 116).

Conceiving of elites as possibly divided into groups with potentially differing interests, as found in the classical writings in elite theory of the nineteenth century, opens possibilities for multiple voices and dispersion of power - key conditions for liberal democracy (Aron, 1950). Pareto's and Mosca's theories on elite pluralism are applicable to contemporary normative discussions on the legitimacy of elites in democratic societies. The legitimacy of elites depends on whether they are one integrated group or several different elites; Mosca and Pareto show that several elites are possible. These insights into elite pluralism starkly contrast with populist ideological understandings of the oppressive elite as necessarily homogeneous and characterised by converging interests.

Despite overwhelming differences between the types of society envisaged and interpreted by Pareto and Mosca and the variety of stable democracies in the modern world, fundamental asymmetries of power between majorities and minorities persist in contemporary democratic societies. The ubiquity of various sorts of large organisations created by far-reaching social differentiation in modern societies contributes to such asymmetries of power between the masses and elites. These organisations' hierarchical structure concentrating most power at the summit makes their top leaders core members of any type of social elite. These organisations' institutional make-up and relationships with the political and societal systems of which they are part are crucial to the kinds of relationships among the different elites at the top. Are they united and conspiring together, as 
populists claim, or do they promote different worldviews and interests? Pareto's and Mosca's theories open up imagining the existence of several elites, but more recent elite theory goes further and focusses on the question of how united these different elites are.

\section{THE POSSIBILITY OF ELITE PLURALISM}

Nearly all modern elite theorists acknowledge a certain diversity of elites, as indicated by traditional elite theory. Wright Mills (1956), Dahl (1961), Field and Higley (1980) and Scott (2008) subscribe to a definition of elites as those occupying leading positions in powerful institutions, to use a formulation by Giddens (1972). The main debate in modern elite theory concerns the degree to which these various elites constitute highly integrated groups defending common interests or, to the contrary, are more dispersed, characterised by differing recruitment patterns, interests, worldviews and patterns of career mobility. Do they form a closed group, power elite in Mills's (1956) term, or is the image of a plurality of elite interest groups more relevant? Those who view elites as integrated and united are often called monists, whereas those who view elites as split into separate, competing groups are called pluralists (Genieys, 2011). Elite theorists disagree on interpretations of the empirical situation in a given society at a particular time (e.g. how integrated American elites were in the 1950s) but generally agree on the normative stance that a plurality of elites is beneficial for democratic societies (Dahl, 1961; Mangset, 2017; Mills, 1956). The importance of the descriptive and analytical discussions on the degree of elite integration to modern elite theorists are important to this chapter as it allows better understanding these power relations and provides a foundation for discussing the normative issue of elites' legitimacy in democratic societies.

Debates and insights from elite theory thus are relevant to discussing two aspects of populism. First, regarding populist ideological understandings of the problem of how a united elite exploit the people, elite theorists focussing on elite integration, such as Mills, present an analysis similar to populism in some respects. Furthermore, elite theorists focussing on elite pluralism, such as Dahl and Higley, agree with populists - and Mills - that if the elites were united and homogeneous, that would represent a problem. Second, modern elite theory is relevant to discussing populist ideological understandings of the solution to replace the current arrangements: undivided political leadership. Monists and pluralists in modern elite theory are both critical of the democratic legitimacy of this populist conceptualisation of political leadership.

Contrary to populist ideological understandings of today's power relations, the degree to which elite groups are integrated and have the capacity for collective action is likely to vary between countries and through history. The institutional structures for recruitment, career patterns and relations between sectors vary by country and time; so do the conditions for elite integration (Hartmann, 2010; Mangset, 2017). Close analyses also show different modes of elite integration (Engelstad, 2018). At the same time, processes of disintegration may be at work. 
We find it most fruitful to regard elite integration not as a defining criterion of elite formation but, rather, as an empirical question (see also Higley \& Burton, 2006; Scott, 2008, p. 34). The degree to which elite groups are integrated and act in concert in any society at any time must be examined empirically. It cannot be stipulated a priori that they are homogeneous and united, as populist leaders tend to claim in their attempts to rhetorically seduce the masses.

\section{VARIETIES OF POPULIST ELITE CRITIQUES}

Although populist ideology ideal-typically conceives of the elite as a united, homogeneous group, populist movements across the world have attacked a range of elite groups and laid different accusations against them. This empirical diversity of elite critiques is interesting as it tells us that populists themselves are well aware that different types of elites exist - in contrast to what their ideological model states. In this section, we look closer at specific versions of populism and populist elite critiques to illustrate this diversity, without aspiring to exhaustivity. After briefly pointing to some features of populist ideologies and organisations that open up this diversity, we examine four types of populist elite critiques.

Several types of populism can be distinguished according to their political orientations and the specific issues at stake. In addition to the common distinctions between right-wing populism generally opposing the state and left-wing populism opposing both the state and advanced capitalism, an intermediate version focuses on the functioning of the democratic system (Kriesi, 2014, p. 362). Populism grows out of a variety of organisations and movements (Aslanidis, 2017; Ciani \& Della Porta, 2017), and its ideas are diffused through several channels (Veugelers \& Menard, 2017). Despite this diversity, political parties are the most central organisations of populist mobilisation. Even if parties are interdependent with less institutionalised movements, movements that seek to make significant differences have to be visible in the political centre, which generally requires being represented by one or more political parties. Hence, the dynamics of populist movements are closely linked to party politics and the dominant political rhetoric.

The points of departure for this brief description of various types of populism and their elite targets are Canovan's (1981) minimal definition and Mudde's (2004) conception of populism as a thin-centred ideology with a limited core of values. In contrast to a thick-centred ideology covering a wide range of societal issues, thin-centred ideologies have specific, limited areas of concern. Other examples of thin-centred ideologies are feminism and ecologism. In the case of populism, its core values are anti-elitism and exaltation of a unified, homogenous people and their general will. Accordingly, populist parties show a high degree of flexibility in the issues they emphasise and the groups they attack and may shift relatively quickly over time.

Central elements in attacks on elites are political rhetoric and rhetorical strategies deployed in general, mediatised political discourses (Kriesi, 2014). They are launched on a particular vector, closely connected to common sense and the vernacular in opposition to abstract reasoning and specialised modes of speech and 
academic jargon. Populist rhetorical strategies are intended to debunk subtleties and replace them with efficient, striking, often derogatory metaphors. It, thus, becomes easy to subsume different types of elites under one heading: The Elite. In the following sketch of variations of elite critiques, the discussion is based on examples collected by ordinary observations in order to complement current research, which, in some respects, is limited in studies on political parties. Our analysis of these examples, which indeed comprise a range of different forms of elite critiques, results in four overarching categories: critiques of political elites, intermediate elites, economic elites and cultural elites.

\section{POPULIST CRITIQUE OF THE POLITICAL ELITE}

The initial impetus for contemporary populism came from tax resistance and the establishment of anti-tax parties in several European countries (Taggart, 1995). The poujadist movement emerged in France in the 1950s, followed by similar parties in Denmark and Norway around 1970. Criticism of the state defined these parties. However, the tax issue declined to secondary importance when waves of immigration to Europe in the 1980s resulted in increased electoral support for populist parties. The turn from taxation to immigration led to a different, somewhat positive view of the state as the guardian of national borders and the source of welfare-state provision.

The immigration issue has become central for two reasons. First, it challenges deep cultural notions of us and them. Second, more implicit but not less significant is the complex question of who constitutes the demos (Kaltwasser, 2014) and can claim the rights of citizenship. Once brought to the fore, immigration and immigration policies became the dominant issue for virtually all populist parties across central, northern and southern Europe, leading to one the European Union's (EU) most serious crises in 2015. The populist standard view is that politicians defending international conventions on refugees and immigration live in isolated bubbles and betray national interests.

In central and southern Europe, criticism has also been directed against corrupt politicians, producing disillusionment with liberal democracy (Pappas, 2014; Stanley, 2017). Accusations of untruthfulness among politicians had a decisive influence in bringing Fidez to power in Hungary (Lengyel \& Szabó, 'The Political Elite and Trust in EU Institutions after the Crisis. A Comparative Analysis of the Hungarian Case', this volume). Distrust in politicians has accompanied protests against welfare policies, motivated by deficits in state budgets in southern Europe and welfare-state chauvinism seeking to deny immigrants the same rights as citizens in northern Europe.

The form of attacks on elites largely depends on the position of populist parties and movements in the political landscape. When operating as opposition forces, some populist parties remain in a challenger position with little formal power, even if they gather considerable electoral support. This situation is the case in France and the United Kingdom owing to their versions of majority elections. However, major populist parties with relatively high parliamentary 
representation sometimes also remain marginal, excluded from government positions. The most startling case is the Freedom Party in the Netherlands, a party with only one member, leader Geert Wilders. Other parties in similar positions are the Swedish Democrats and the Alternative für Deutschland in Germany. However, their isolation in parliaments does not prevent them from constant pressuring mainstream politics and politicians, thereby exerting considerable influence as agenda setters.

A different situation emerges when populists gain government positions. They must adjust their rhetoric but continue to depict themselves as outsiders of the political system by directing their elite critique at elite groups other than their own government (Silva, 2017, p. 7). Populist parties long have been minorities in government coalitions in several countries, notably Finland, Norway, Switzerland and Austria. Major effects of their political position have been significant adjustments and moderation in these populist parties.

In post-communist Hungary and Poland, populist parties have gained majorities by winning national elections on anti-elite programmes targeting previous governments' political corruption. Majority power has empowered them to set out to transform political institutions to their own advantage, making relatively liberal regimes nationalistic and conservative and placing growing limitations on the critical press and oppositional civil society organisations (Stanley, 2017). Before coming to power, these populist parties directed their rhetoric against national elites, and as incumbents, they redirect their hostility to the EU's bureaucratic elite.

Resistance to the EU and claims of restoring national sovereignty have become hallmarks of populist movements all over Europe. In southern Europe (Greece and Italy), populist parties have especially directed attacks against membership in the eurozone. In France, Front National (renamed Rassemblement National) has voiced general scepticism of the EU for many years (Ivaldi, 2018; Vasilopoulou, 2011, 2017). Resistance to EU membership was even more forcefully expressed in the Brexit slogan of 'Take our country back'. ${ }^{2}$ In addition to the assumption that staying outside the EU will benefit the welfare of the people, these attacks reflect profound concerns about political legitimacy. Put simply, the core question of legitimacy is 'Who should rightfully decide over me?' Despite considerable efforts to build a European citizenship, the core of political legitimacy remains anchored in nation-states. This duality of national and European citizenship has created a deep ambiguity that has become a driving force in protests against the EU and its bureaucratic elite.

\section{POPULIST CRITIQUE OF INTERMEDIATE ELITES}

The populist ideal of strong leadership by a single person who interprets and articulates the people's will also implies scepticism towards a plurality of institutions and intermediate bodies. In line with Mosca's theory, the anti-elitism in populist movements is not necessarily or not only directed towards the top political elite but also often towards elite groups immediately below the political leader of a country or a political system. Thus, the president or the prime minister, especially if also the 
head of a populist movement, is not necessarily the main target of elite critiques. The target may well be the leadership of political parties and central institutions such as public agencies, central banks, educational institutions and unions. This is well illustrated by the Greek activists demonstrating before the parliament during the euro crisis, who resolved not to leave the Syntagma Square "until all those who led us here are gone: governments, the Troika, Banks, Memoranda, and all those who take advantage of us' (Aslanidis, 2017, p. 310). The critique of leaders and bureaucrats in international institutions, such as the EU, has strong connections with the critique of these various types of intermediate elites discussed here.

Rejection of classical political parties and preferences for less formally organised political movements have characterised Europe in our times. In the literature, the lack of trust in political institutions is often cited as a cause and a consequence of populism (Silva, 2017, p. 7). Peter Mair (2002) and Hanspeter Kriesi (2014) tied the rise of populism in Europe to the erosion of political parties' legitimacy as representatives of the voters (Manin, 2012 [1995]).

The failure of mainstream parties to effectively articulate and represent policy preferences that are salient to a significant portion of the electorate is ... a widely recognized source of new party formation[s] ... in established democracies. (Roberts, 2017, p. 294)

Among political institutions, the civil service is a main target of populist movements. When institutions - whether public agencies, party organisations, unions or others - are considered to be central components of the political system, it implies that the political system constrains power with bureaucratic rules. The legal-rational authority of central institutions restricts top leaders' power, particularly in the domains which they control and the procedures they must follow to legitimise their exercise of power. A dominant stereotype is inefficient bureaucrats operating without any thought of useful outcomes or consideration of citizen welfare. These bureaucrats are obsessed with rules and regulations, but at the same time, they are thought to fight for their own interests or some version of a 'deep state' (Osnos, 2018). They can continue to do so as the 'government has been captured by powerful special interests that enslave and impoverish the many to enrich the few' (Silva, 2017, p. 3). This view in particular has been expressed in the United States, where then presidential candidate Donald Trump repeatedly promised to 'drain the swamp' of the Washington bureaucracy, as did Ronald Reagan before him (Garcia, 2016). To circumvent bureaucratic obstruction, populists cherish forms of direct democracy, such as referenda, over the lengthier functioning of parliamentary processes and, above all, the civil service. This attitude has been most strongly emphasised by the Italian Five Star and the French yellow-vests movements but is prevalent even throughout more moderate populism in Scandinavia (Widfeldt, 2017, p. 522).

\section{POPULIST CRITIQUE OF ECONOMIC ELITES}

In the critique of economic elites, a clear divide between left- and right-wing populism comes to the fore. Left-wing populism remains strongest in Latin America, 
where populist parties have long held a position taken by social democratic parties in other parts of the world (Roberts, 2017, p. 290). However, the Latin American elite contains a strong coalition of landowners and capitalists. Left-wing populism is also visible in southern Europe, manifested in parties such as Syrizia and Podemos and the spontaneous movement La France insoumise. The French yellow-vests movement cannot clearly be defined as left-wing populism as it is composite and expresses a range of elite critiques and political demands. However, key tenets of the protesters are demands to re-establish taxes on wealth and enact more redistributive taxation and economic justice in general. Anti-capitalist agitation and critiques of economic elites, albeit more moderate, are also voiced by the left-wing populist movements and parties led by Bernie Sanders in the United States and Jeremy Corbyn in the United Kingdom.

Although left-wing populism undeniably exits, right-wing populist rhetoric has been the most noticeable in the political scene in central European and north Atlantic countries. Despite considerable populist support in the working classes, the conflicts between labour and capital - stressed throughout most of the twentieth century - are little discussed. For considerable segments of the working class, visions of class struggle have been replaced by the gap between the people and the political elite (Oeusch, 2008). This is noteworthy as large-scale immigration and importation of labour have accompanied dismantling of traditional industries in Europe, both inside and outside the EU. Even amid high unemployment rates, though, economic elites have largely been exempt from right-wing populist attacks.

At the same time, populist do not appear to consider economic inequality to be a serious problem. It is not prominent on the agendas of the French Rassemblement National or the Dutch Freedom Party. The Brexit campaign was initiated by the deeply conservative faction of the Tory Party but would not have succeeded without strong support in regions hit by high unemployment. In the Czech Republic, billionaire Andrej Babiš won the 2017 presidential election. On the other side of the Atlantic, the president is a billionaire, and the present US cabinet members have the highest average income in cabinet history.

Here, one reservation should be noted. Criticism of the economic elites is more often targeted at the financial elite. In the most recent US presidential campaign, Wall Street was a visible target, as was London City in the Brexit campaign. The activities of economic analysts and financial sector employees are not necessarily more mysterious than those in the corporate sector, but they do not produce tangible, useful products or create jobs that most people can fill. Hence, they remain at a distance from the majority of the population and thus may serve as useful targets in populist rhetoric when billionaires compete for political positions.

\section{POPULIST CRITIQUE OF THE CULTURAL ELITE}

Populism is a question of not only politics and parties but also political style (Knight, 1998). The distinction between high and low culture emerges as a constant characteristic of populism, transcending variations in political issues or geography: 'despite the very local nature and texture of all populisms, 
cross-continentally they are characterized by a surprisingly similar affective narrative' (Ostiguy, 2017, p. 75). Focussing on these cultural components enriches understanding of populism as a phenomenon and yields a more comprehensive view of the variety of elite groups targeted by populism. The theoretical approach to cultural expression summarises social identity and political appeal in a notion of populism's affective narrative. 'High' groups comprise a variety of artists, academics, experts and media leaders who share the power of definition in the public sphere. 'Low' groups, in this context, do not embody economic status or social positions but direct-from-the-liver ways of speaking. Examples of rich people and prominent politicians classified as culturally low flourish; Trump and Silvio Berlusconi are only the most visible illustrations. In contrast, intellectuals' contrived sophistication reveals a bloodless elite.

These coarse claims of authenticity are not the only form of anti-elite opposition. Scientists and academic elites, obviously in the social sciences but also the natural sciences, are also targets. Justified by personal experiences and beliefs and accordingly by claims of authenticity, populists reject, if not ridicule, statements on climate change from the United Nations Climate Panel. By implication, statements on climate change may be dismissed not only by pointing to contrasting observations over relatively short periods but also by exaggerating the doubts attached to any scientific findings. The scientific methodology thus is used to invalidate well-established scientific results (Jasanoff, 2010).

Disbelief in various forms of expertise extends from the sciences to other types of professional expertise. The increased complexity of political issues widens the gaps among the people, elites and experts with high academic credentials. 'I think that the people of this country have had enough of experts with organisations from acronyms, saying that they know what is best and getting it consistently wrong', Michael Gove, then minister of justice, declared during the Brexit campaign (Sky News, 6 June 2016). While experts might issue wrong judgements owing to one-sided application of their expert knowledge, the attacks on them have a broader cultural basis than the (in)correctness of their views based on an assumption that their views are formed without consideration of the world's practical demands.

Modern art is under constant attack as out of touch with the people or impossible to understand. For instance, a Norwegian populist politician suggested converting the National Theatre into a bingo hall. A more sophisticated version is an alliance of cultural conventionality with distaste for modern art. The official establishment of a national canon of arts and literature consisting primarily of traditional works from the nineteenth century has been a central cause for the Danish People's Party. An implicit link to immigration emerges: if all citizens are to embrace the canon, then immigrants are forced to accept it as a sign of sincere belonging to the host country. Similarly, the Danish People's Party and the Norwegian Progress Party turned from their former resistance to gender-equality policies - typically an issue supported by the cultural elites - to embrace of gender equality as a national value threatened by immigrants from Islamic countries. Gender-equal attitudes and practices thus became a sign of willingness to integrate into 'our' culture (Dahlerup, 2018; Teigen \& Wägnerud, 2009). 
In contrast to the cultural elites and their special manners and modes of expression, media messages are relatively easily accessible, both physically and linguistically. The main populist critique of the media is its alleged hypocrisy, selectively presenting, twisting or simply inventing facts as it belongs to the same elite it purportedly critiques. The slogans travel all over the western world, from fake news originating in the United States to Lügenpresse in Germany: 'Donald Trump calls journalists liars, Geert Wilders tells the critical media to "drop dead", Marine Le Pen calls them a "self-proclaimed elite", and Nigel Farage accuses them of bias' (Ellinas, 2017, p. 269). The unanimous attack on the media has several sources, including the dramatically increased competition from social media and the low investments necessary to set up alternative news media on the internet. At the same time, the media itself has contributed to these attacks. Professional journalistic criteria have given broad coverage to populist parties and groups, disseminating and normalising populist conceptions (Ellinas, 2017, p. 279).

The various types of elite critiques promoted by populists around the world could be categorised differently. However, we consider that pointing to the critiques of these four categories of elites (political, intermediate, economic and cultural elites) highlights the key features and variety of populist elite critiques, supporting further analysis of the elitist dimensions of populism and the relationship between elites and democracy. Discussing political, economic and cultural elites points to different segments of society that may be organised by competing logics and understandings of value and thus breeds different types of elites that do not necessarily cooperate. We also highlight intermediate elites, although these can exist in the three spheres of society (political, economic and cultural). However, by treating intermediate elites as a distinct group, we specifically identify bureaucratic elites central to our political, administrative and democratic institutions and distinct from politicians in their source of legitimacy. Furthermore, we shed light on the specific populist critiques of these power bases that lie between the people and the political leadership. Critiques of these elites are central to populist ideological conceptualisations of the ideal relationship between the people and the leader and are central to the elitist character of populism.

\section{DEMOCRACY AND THE UNITY OF ELITES?}

The various forms of populism identified across the world target a range of different elites. In this way, the empirical reality of populist elite critiques accords more with elite theorists' notion of plural elites than the populist ideal-typical conceptualisation of the united elite. Although different populists target different elite groups, the degree of unity among these elite groups remains a question. It has been discussed in depth in modern elite theory, which accordingly can be fruitful in the discussion on populist elite critiques. Furthermore, elite theories' normative discussion on the relationship between elite pluralism and democracy is also relevant to the discussion on the inherent elitism in populist ideas of leadership.

Are the various elite groups in society common, coherent elite or varied competitors? Why does it matter? As briefly mentioned, the monists following 
the scholarly tradition of Mills (1956) tend to focus on how closely connected various elite groups are. The pluralists who follow Dahl (1961) stress the diversity of elites. Both strands generally agree on the normative stance that elite pluralism is better for democracy than a too integrated and united elite, but they disagree on the descriptive issue of how integrated elites are. With disagreements on both conceptual issues and interpretations of empirical facts, a final conclusion on the empirical realities is difficult to reach. However, they agree on the significance of the degree of elites' integration to the functioning of democracy. Challenges to democracy can come from too integrated elites that largely share life conditions and ways of perceiving the world and their interests.

Furthermore, elite theory demonstrates the usefulness of explicitly discussing which mechanisms can be relevant to increasing, preventing or decreasing integration of elite groups (for more, see Engelstad, 2018; Mangset, 2017). A useful point of departure may be John Scott's (2008) description of the mechanisms of elite integration and power concentration:

\begin{abstract}
As occupants of a purely formal category, the members of an elite need have few bonds of interaction or association and may not exist as a cohesive and solidaristic social group. Such solidarity occurs only if social mobility, leisure time socializing, education, intermarriage, and other social relations are such that the members of an elite are tied together in regular and recurrent patterns of association. Only then are they likely to show any unity or to develop common forms of outlook and social consciousness. (Scott, 2008, p. 34)
\end{abstract}

The mechanisms mentioned by Scott can be described as a cultural mode of elite integration, which can be reinforced by career circulation: the more elite members move between jobs, for example, from public agencies to politics and business, the more integrated the administrative, political and business elites are thought to be (Hartmann, 2007, 2010; Mangset, 2017). Dahlström, Lapuente, and Teorell (2011) described yet another form of elite group relations that can be analysed as a form of elite integration. For example, when bureaucrats and politicians, two supposedly distinct elite groups in the governing system, are not separated by clearly different career patterns and motivational structures, they can become too interdependent and develop a unified outlook on their work, world and common interests. Thereby, not only cooperation but also corruption among bureaucrats and politicians is facilitated. This can be analysed as a case of elite integration from merging professional structures. More general sources of elite integration are overarching structures, such as social and political norms and institutions (Engelstad, 2018), and certain ideologies and political orientations more prone to elite integration (Gulbrandsen, 2019).

Our point is that elites cannot a priori be assumed to be a coherent, united group as populist ideal-typical ideology defines them. The degree to which elites meet, socialise and interact in ways that open up the development of common interests and ways of understanding the world should be investigated. Moreover, the institutional structures that can underpin development of common worldviews and interests and the institutional structures that prevent such development should be examined. 


\section{CONCLUDING REMARKS}

Given the variety of elite critiques, populist movements' failure to always direct their critiques against the same groups and to always level the same accusations indicate that there are different elite groups and different forms of populism. This contradicts populist ideal-typical ideological conceptions of power relations as one between a homogeneous, oppressed people and homogeneous, malevolent and dominant elite. The extensive literature on populism presents a wide variety of perspectives, but all share anti-elitism as a defining characteristic. However, populism is inherently elitist in two senses. First, analytically, populism conceives of power relations in society as existing between a homogeneous, unified, good people oppressed by a group of homogeneous, unified and malevolent elite. Perceiving the holders of power as a small, unified elite group can be said to be an elitist perception of the power distribution in society. Second, normatively, populism prefers a political system in which a strong leader takes power from the oppressive elites and governs with few restrictions from institutional structures and intermediate elites. The populist view on adequate political leadership understands the leader as one who almost singlehandedly channels the people's will through a charismatic capacity for understanding and interpreting the people's wishes. The vision of a political system without institutionalised intermediate elites and counter-elites and with few legitimate counter-voices in the government decision-making processes is especially elitist and a challenge to democracy.

Elite theory, from its inception, has pointed to the existence of different types of elites. Some may argue that those among elite theorists who have insisted on the strong bonds among elite groups have fed populists' conspiratorial understanding of elites as homogeneous, united and fighting for their common interests. We argue that the rise of populism in our times and indeed populist parties' electoral wins and entry into the governments in several countries make it all the more important to seek inspiration from both sides in this debate in elite theory: those focussing on elite integration and those insisting on elite plurality. Doing so is necessary to investigate the degree of elite integration in contemporary societies, as well as the underpinning institutional structures. Social scientists should empirically establish how integrated elites are in different societies in order to inform political debates. If populist ideological conceptualisations of elites as homogeneous and fighting for common interests are accurate - in a specific society at a specific time - they are as challenging to democracy as populist movements themselves. Furthermore, elite studies in the social sciences should renew the debate on the conditions for elite groups to play a more constructive role in securing institutional restrictions on political leadership, the distribution of power and the democratic exchange of ideas necessary to sustain liberal democracy.

Sociological critiques of elites' growing, illegitimate power and privileges (Piketty, 2014; Savage \& Williams, 2008) are needed as the widening gap between the elites and people contributes to the unfairness and frustration initially motivating the rise of populism. Indeed, sociologists have a responsibility to shed light on the power held and used by economic elites as these tend to escape much populist critique. However, sociologists should be able to combine a nuanced critique 
and discussion on certain elite groups' roles in liberal democracies: a role both as a source to legitimate populist protest and of possible counter-voices and a balance of power. Elite groups' legitimacy as counter-voices and powerful actors clearly depends on the degree and form of their access to elite positions.

\title{
ACKNOWLEDGEMENT
}

\author{
Open Access Funded by Centre for the Study of Professions, Oslo Metropolitan \\ University.
}

\section{NOTES}

1. One can say that the degree of the plurality of elites is related to the degree of autonomy in each field or the development of institutional boundaries between fields. We return to this question in the discussion on elite integration.

2. After seeing British politicians' struggle to handle Brexit, some EU-sceptical populist parties, such as the French RN (previously the FN), have moderated their demand to leave the EU into a call to change it from within.

\section{REFERENCES}

Aron, R. (1950). Social structure and the ruling class: Part 1. British Journal of Sociology, 1(1), 1-16. Aslanidis, P. (2017). Populism and social movements. In C. R. Kaltwasser, P. Taggart, P. O. Espejo, \& P. Ostiguy (Eds.), The Oxford handbook of populism (pp. 305-325). Oxford: Oxford University Press.

Canovan, M. (1981). Populism. New York, NY: Harcourt Brace Jovanovich.

Canovan, M. (1999). 'Trust the people!' Populism and the Two Faces of Democracy. Political Studies, 47(1), 2-16.

Ciani, M., \& Della Porta, D. (2017). The radical right as social movement organizations. In J. Rydgren (Ed.), The Oxford handbook of the radical right (pp. 327-347). Oxford: Oxford University Press.

Coenen-Huther, J. (2004). Sociologie des élites. [Sociology of elites.] Paris, France: Armand Colin.

Dahl, R. A. (1961). Who governs? Democracy and power in an American city. New Haven, CT: Yale University Press.

Dahl, R. A. (1989). Democracy and its critics. New Haven, CT: Yale University Press.

Dahlerup, D. (2018). Gender equality as a closed case. A survey among the members of the 2015 Danish Parliament. Scandinavian Political Studies, 41(2), 188-209. doi:10.1111/1467-9477.12116

Dahlström, C., Lapuente, V., \& Teorell, J. (2011). The merit of meritocratization: Politics, bureaucracy, and the institutional deterrents of corruption. Political Research Quarterly, 65(3), 656-668. doi: 1065912911408109

Ellinas, A. A. (2017). Media and the radical right. In J. Rydgren (Ed.), The Oxford handbook of the radical right (pp. 269-284). Oxford: Oxford University Press.

Engelstad, F. (2018). Models of elite integration. In H. Best \& J. Higley (Eds.), The Palgrave handbook of political elites (pp. 439-457). London: Palgrave Macmillan.

Field, G. L. \& Higley, J. (1980). Elitism. London, UK: Routledge \& Kegan Kegan Paul.

Garcia, E. (2016). A history of 'draining the swamp'. Roll Call. Retrieved from http://www.rollcall .com/news/politics/history-of-draining-the-swamp. Accessed on November 15, 2016.

Genieys, W. (2011). La sociologie des élites politiques [The sociology of political elites]. Paris, France: Armand Colin.

Giddens, A. (1972). Elites in the British class structure. Sociological Review, 20(3), 345-372. 
Gulbrandsen, T. (2019). Elites in an egalitarian society: Support for the Nordic model. London, UK: Palgrave Macmillan.

Hartmann, M. (2007). Eliten und Macht in Europa: ein internationaler Vergleich [Elites and power in Europe: an international comparison]. Frankfurt, Germany: Campus Verlag.

Hartmann, M. (2010). Elites and power structure. In S. Immerfall \& G. Therborn (Eds.), Handbook of European societies (pp. 290-324). New York, NY: Springer.

Higley, J., \& Burton, M. (2006). Elite foundations of liberal democracy. Lanham, MD: Rowman \& Littlefield.

Ivaldi, G. (2018). Contesting the EU in times of crisis: The Front National and politics of euroscepticism in France. Politics, 38, 278-294.

Jasanoff, S. (2010). A new climate for society. Theory, Culture \& Society, 27, 233-253.

Kaltwasser, C. R. (2014). The responses of populism to Dahl's democratic dilemmas. Political Studies $62,470-487$.

Kazin, M. (1998). The populist persuasion: An American history. Ithaca, NY: Cornell University Press.

Knight, A. (1998). Populism and Neo-populism in Latin America, especially Mexico. Journal of Latin American Studies, 30(2), 223-248.

Kriesi, H. (2014). The populist challenge. West European Politics, 37(2), 361-378.

Laclau, E. (2005). On populist reason. London: Verso.

Mair, P. (2002). Populist democracy vs party democracy. In Y. Mény \& Y. Surel (Eds.), Democracies and the populist challenge (pp. 81-98). London: Palgrave Macmillan.

Manin, B. (2012 [1995]). Principes du gouvernement représentatif [Principles of representative government]. Paris, France: Calmann-Lévy.

Mangset, M. (2015). What does it mean to be part of the elite? Comparing British, French and Norwegian top bureaucrats understanding of the elite concept when applied to themselves. Comparative Sociology, 14(2), 274-299.

Mangset, M. (2017). Elite circulation and the convertibility of knowledge. Comparing different types and forms of knowledge and degrees of elite circulation in Europe. Journal of Education and Work 30(2), 129-144. https://doi.org/10.1080/13639080.2017.1278903

Meny, Y., \& Surel, Y. (2001). Democracies and the populist challenge. New York, NY: Springer.

Mills, C. W. (1956). The power elite. Oxford: Oxford University Press.

Mosca, G. (1939 [1896]). The ruling class. New York, NY: McGraw-Hill.

Mudde, C. (2004). The populist zeitgeist. Government and Opposition, 39(4), 541-563.

Oeusch, D. (2008). Explaining workers' support for right-wing populist parties in Western Europe: Evidence from Austria, Belgium, France, Norway and Switzerland. International Political Science Review, 29, 349-373.

Osnos, E. (2018). Trump vs. the "deep state". The New Yorker, May 21. Retrieved from https://www. newyorker.com/magazine/2018/05/21/trump-vs-the-deep-state. Accessed on July 27, 2019.

Ostiguy, P. (2017). Populism: A socio-cultural approach. In C. R. Kaltwasser, P. Taggart, P. O. Espejo, \& P. Ostiguy (Eds.), The Oxford handbook of populism (pp. 73-99). Oxford: Oxford University Press.

Pappas, T. S. (2014). Populist democracies: Post-authoritarian Greece and Post-communist Hungary. Government and Opposition, 49, 1-23.

Pareto, V. (1963). Mind and society: A treatise on general sociology. New York, NY: Dover Publications. Piketty, T. (2014). Capitalism in the $21^{\text {st }}$ century. Cambridge, MA: Harvard University Press.

Roberts, K. M. (2017). Populism and political parties. In C. R. Kaltwasser, P. Taggart, P. O. Espejo, \& P. Ostiguy (Eds.), The Oxford handbook of populism (pp. 287-304). Oxford: Oxford University Press.

Savage, M., \& K. Williams (Eds.). (2008). Remembering elites. Oxford: Blackwell.

Scott, J. (2008). Modes of power and the re-conceptualization of elites. In M. Savage \& K. Williams (Eds.), Remembering elites (pp. 27-43). Oxford: Blackwell.

Silva, B. C. (2017). Contemporary populism: Actors, causes, and consequences across 28 democracies. Budapest, Hungary: Central European University, Doctoral School of Political Science, Public Policy and International Relations.

Sky News. (2016, June 6). https://www.youtube.com/watch?v=t8D8AoC-5i8. Accessed on 27 July, 2019. 
Stanley, B. (2017). Populism in Central and Eastern Europe. In C. R. Kaltwasser, P. Taggart, P. O. Espejo, \& P. Ostiguy (Eds.), The Oxford handbook of populism (pp. 140-160). Oxford: Oxford University Press.

Taggart, P. (1995). New populist parties in Western Europe. West European Politics, 18, 34-51.

Taggart, P. (2000). Populism. Buckingham: Open University Press.

Teigen, M., \& Wägnerud, L. (2009). Tracing gender equality cultures: Elite perceptions of gender equality in Norway and Sweden. Politics \& Gender, 5, 29-44.

Vasilopoulou, S. (2011). European integration and the radical right: Three patterns of opposition. Government and Opposition, 46, 223-244.

Vasilopoulou, S. (2017). The radical right and euroskepticism. In J. Rydgren (Ed.), The Oxford handbook of the radical right (pp. 122-140). Oxford: Oxford University Press.

Veugelers, J., \& Menard, G. (2017). The non-party sector of the radical right. In J. Rydgren (Ed.), The Oxford handbook of the radical right (pp. 285-304). Oxford: Oxford University Press.

Weber, M. (1992 [1921]). Economy and society. Berkeley, CA: University of California Press.

Widfeldt, A. (2017). The radical right in the Nordic Countries. In J. Rydgren (Ed.), The Oxford handbook of the radical right (pp. 545-564). Oxford: Oxford University Press. 